June 1993

\title{
The Psychoanalytic Approach to Bulimia
}

Doris Mirowski, M.D.

Thomas Jefferson University

Follow this and additional works at: https://jdc.jefferson.edu/jeffjpsychiatry

Part of the Psychiatry Commons

Let us know how access to this document benefits you

\section{Recommended Citation}

Mirowski, M.D., Doris (1993) "The Psychoanalytic Approach to Bulimia," Jefferson Journal of Psychiatry. Vol. 11 : Iss. 2 , Article 13.

DOI: https://doi.org/10.29046/JJP.011.2.011

Available at: https://jdc.jefferson.edu/jeffjpsychiatry/vol11/iss2/13

This Article is brought to you for free and open access by the Jefferson Digital Commons. The Jefferson Digital Commons is a service of Thomas Jefferson University's Center for Teaching and Learning (CTL). The Commons is a showcase for Jefferson books and journals, peer-reviewed scholarly publications, unique historical collections from the University archives, and teaching tools. The Jefferson Digital Commons allows researchers and interested readers anywhere in the world to learn about and keep up to date with Jefferson scholarship. This article has been accepted for inclusion in Jefferson Journal of Psychiatry by an authorized administrator of the Jefferson Digital Commons. For more information, please contact: JeffersonDigitalCommons@jefferson.edu. 


\title{
Book Reviews
}

\section{The Psychoanalytic Approach to Bulimia}

\author{
BULIMIA: PSYCHOANALYTIC TREATMENT AND THEORY \\ Harvey J. Schwartz, M.D., Ed. \\ International Universities Press, Inc., Madison, CT. \\ 1990 (second edition), 549 pages, $\$ 65.00$.
}

\section{Doris Mirowski, M.D.}

Bulimia: Psychoanalytic Treatment and Theory is good reading for any resident who wishes for a more complete understanding of the condition. Harvey J. Schwartz, M.D. edited and contributed to this comprehensive sixteen chapter book covering a wide range of topics regarding bulimia. The book evolves from an overview of analytic concepts and general theories to specific conditions such as pregnancy, work inhibition and addictive behavior.

In quick summary, the analytic theory is that the bulimic's development results from a mother's symbolic unavailability during the patient's development. There is maternal ambivalence towards the child and her use of the child for her own narcissistic needs. The father is found to be overstimulating and seductive, and the patient has early and frequent exposure to primal scenes. An analogy is drawn between the devouring of food by the patient and forcing the finger into her throat with resulting regurgitation as representing a simultaneous identification with both parents.

The secretiveness that is inherent to bulimia belies its heavy presence in high functioning adults. The condition is certainly not incongruous with achievement and professional success. It is a common disorder among female doctors and nurses as well as among other professionals. People with bulimia are often married and are frequently more sexually active than anorexics. Depression is more commonly reported in bulimia but suicide and death from complications are not characteristic. For a high functioning professional it is surprisingly easy to empathize with the patients described in this text; thus one finds while reading it an increasing desire to understand bulimia beyond the DSM-III-R.

Daniel Gesensway, M.D. emphasizes in his chapter "Bulimia and Pregnancy" that the syndrome is not one of an eating disorder but reflects underlying personality disturbances. This chapter was clear and, along with addressing pregnancy, established a strong foundation for an analytic understanding of bulimia. In an earlier chapter C.J. Tabin and J.K. Tabin write that "what distinguished the bulimic or 
anorexic from the normal dieter is not the cultural setting but the level of ego organization on which her actions are based." This chapter includes the case example of a male bulimic that helps to clarify the different psychic conflicts for boys compared to those of girls. Since bulimics are usually female, the breakdown of analytic differences between genders was beneficial and valuable.

Although the book is about bulimia, it becomes evident that it must review anorexia nervosa also. Martin Ceasar's chapter investigates this continuum from a psychologic and intrapsychic perspective. By the end of the book, one becomes aware that bulimia is not defined solely as gorging and purging. There is an addictive element in bulimia that can manifest in anything from shopping binges to kleptomania. Anorexia is examined also, along with the distinction between restrictive anorexia and "fat-phobia." Unfortunately, there is not a final review of the wide range of bulimic manifestations and other eating behaviors.

Not all the chapters take on a hard core analytic tone. Although thought provoking, I found that at my level of training I could not completely grasp some of the analytic views. The more straight forward, practical chapters seemed to have more retainable information. The book has an abundance of case material and discussion that is valuable in anchoring some abstract theory. I felt Dr. Schwartz's first chapter, "Psychoanalytic Perspectives" would be more enriching at the end of the book; it was at that point that I could appreciate the thorough overview of analytic theory that initially seemed overwhelming.

There is one chapter by Harold Boris, M.D., "Torment of the Object," that stands out for its distressing style. One is uncertain if it is not meant to be an exciting short story. A particular case is presented dramatically, at times seemingly unempathically, with some weaving of relevant observations. The tone appears to be mildly sarcastic, with the patient described as a "sorceress" in her ability to manipulate others. The chapter's summary in the book's introduction adds greatly to its value in that it clarifies the intrafamilial unconscious communication, and the impact on the analyst. The style however is lax in showing respect for the patient and her family.

Overall, the book is an illuminating and powerful accumulation of knowledge regarding manifestations of the personality disturbances in bulimia and anorexia, the families that create such people and analytic approaches to the treatment of the patient and the family. At times there is the sense that it is a compilation of isolated papers due to the repetition of basic ideas in many of the chapters. This does give the book a slightly unpolished quality but I found the repetition to be helpful overall in enforcing the general ideas. I put it in my book case with a comfortable understanding of bulimia's complexity. 